\title{
Evaluation RNAi silencing in the DH82 canine histiocytic sarcoma cell line
}

\author{
Gabriel Silva*, Natália Yumi Noronha, Tatiana Takahasi Komoto, Ana Lúcia Fachin, Mozart Marins \\ From 5th Congress of the Brazilian Biotechnology Society (SBBIOTEC) \\ Florianópolis, Brazil. 10-14 November 2013
}

\begin{abstract}
Background
Cancer is a leading cause of death among dogs worldwide [1]. The disease results from alterations in expression of genes that control the cell cycle, including proliferation, differentiation and programmed cell death [2]. The interest in understanding the molecular aspects of cancer in humans and dogs is driven by the possibilities of identification of novel targets for the development of new anticancer compounds [3]. A molecular tool that has been used for this purpose is the RNA interference (RNAi) technique which exploits the mechanism of posttranscriptional silencing, mediated by molecules of double-stranded RNA that trigger degradation of complementary mRNAs [4]. However, for the application of this technique, important aspects must be investigated, since not all cell strains are susceptible to silencing by RNAi, and often the intracellular release of the interfering RNAs has low efficiency [5]. In this work we evaluated the efficiency of RNAi in silencing of topoisomerase IIA, a target for many anticancer compounds, in the canine histiocytic sarcoma DH82 cell line.
\end{abstract}

\section{Materials and methods}

DH82 cells at a concentration of $2,4 \times 10^{5}$ cells/well were cultured in 6 and 24 well plates at $37^{\circ} \mathrm{C}$ and $5 \% \mathrm{CO}_{2}$. Next, siRNAs (small interfering RNA) designed to target topoisomerase IIA and glyceraldehyde-3-phosphate dehydrogenase (positive control) mRNA were introduced into cells with the kit N-TER Nanoparticle siRNA Transfection System (Sigma Aldrich ${ }^{\circledR}$ ). The cells were incubated for 24 hours with a solution of nanoparticles, comprising siRNA (20-30 nM) complexed to peptides N-TER. After transfection, the silencing was confirmed by real time PCR using TaqMan Gene Expression Assays (Applied Biosystems ${ }^{\circledR}$ ). The $\Delta \Delta C$ t method was used for calculating differences in gene expression levels between the untransfected and transfected cells. The level of expression is shown as a fold change positive (induction) or negative (repression).

\section{Results and discussions}

Silencing of topoisomerase IIA (top IIA) and glyceraldehyde-3-phosphate dehydrogenase (GAPDH) was confirmed by obtaining negative fold change. Following transfection in 6-well plates, it was obtained a fold change of $-2,56$ and $-1,35$ for the top IIA and GAPDH genes, respectively. The level of silencing of type IIA decreases after incubation of the transfected cells in the absence of siRNA, as demonstrated by reduced values of the fold change for $-0,95$ and $-0,82$ after 24 and 48 hours of incubation, respectively. The transfection in 6 and 24 well plates resulted in silencing of the top IIA of $-2,56$ and $-0,73$. The use of 24 well plate for transfection, possibly facilitates the internalization of siRNA/peptide complex by cells. The increased concentration of siRNA from 20 to $30 \mathrm{nM}$ did not result in increased silencing of the top IIA.

\section{Conclusions}

The lineage DH82 demonstrated susceptibility to silencing mediated by RNAi. The use of RNAi technique in this cell lineage when performed under ideal conditions of transfection was efficient, allowing the use of this model as a tool to assist in the identification of new targets for the development of new anticancer drugs.

\section{Financial support}

This work was supported for CAPES and FAPESP.

Universidade de Ribeirão Preto, Ribeirão Preto, SP, Brazil 


\section{References}

1. Merlo DF, Rossi L, Pellegrino C, Ceppi M, Cardellino U, Capurro C, Ratto A, Sambucco PL, Sestito V, Tanara G, Bocchini V: Cancer incidence in pet dogs: findings of the Animal Tumor Registry of Genoa, Italy. Journal of Veterinary Internal Medicine 2008, 22(4):976-984.

2. Hanahan D, Weinberg RA: Hallmarks of cancer: the next generation. Cell 2011, 144(5):646-674.

3. Bric A, Miething C, Bialucha CU, Scuoppo C, Zender L, Krasnitz A, Xuan Z, Zuber J, Wigler M, Hicks J, McCombie RW, Hemann MT, Hannon GJ, Powers S, Lowe SW: Functional identification of tumor-suppressor genes through an in vivo RNA interference screen in a mouse lymphoma model. Cancer Cell 2009, 16(4):324-335.

4. Burgess DJ, Doles J, Zender L, Xue W, Ma B, McCombie WR, Hannon GJ, Lowe SW, Hemann MT: Topoisomerase levels determine chemotherapy response in vitro and in vivo. Proceedings of the National Academy of Sciences of the United States of America 2008, 105(26):9053-9058.

5. Wagner S, Willenbrock S, Nolte I, Murua Escobar H: Comparison of noncoding RNAs in human and canine cancer. Frontiers in Genetics 2013, 4:46.

doi:10.1186/1753-6561-8-S4-P158

Cite this article as: Silva et al:: Evaluation RNAi silencing in the DH82 canine histiocytic sarcoma cell line. BMC Proceedings 2014 8(Suppl 4):P158.

\section{Submit your next manuscript to BioMed Central} and take full advantage of:

- Convenient online submission

- Thorough peer review

- No space constraints or color figure charges

- Immediate publication on acceptance

- Inclusion in PubMed, CAS, Scopus and Google Scholar

- Research which is freely available for redistribution

Submit your manuscript at www.biomedcentral.com/submit
(Ciomed Central 